\title{
TIPE SETTING TERITORI TERAS AKIBAT AKTIVITAS TAMBAHAN PENGHUNI DI PERMUKIMAN PESISIR SUNGAI KAPUAS
}

\author{
M. Nurhamsyah \\ Program Studi Teknik Arsitektur, Fakultas Teknik, Universitas Tanjungpura \\ nurhamsyahmuhammad@gmail.com
}

Nicko Maindra Saputro

(Mahasiswa) Program Studi Teknik Arsitektur, Fakultas Teknik, Universitas Tanjungpura

nickomaindra@gmail.com

\begin{abstract}
Abstrak
Teras merupakan ruang tambahan yang berfungsi untuk mewadahi aktivitas tambahan penghuni rumah. Teras juga berperan sebagai ruang transisi yang bersifat publik. Pemakaian teras yang fleksibel merupakan salah satu alasan terbentuknya teras. Teritori teras dapat tercipta dari pola perilaku penghuni yang melakukan kegiatan di teras yang berulang dan konstan. Lokasi penelitian berada di daerah pesisir kampung Bansir Laut, Kecamatan Pontianak tenggara, Kalimantan Barat. Topologi permukiman kampung Bansir yang merupakan permukiman pinggiran sungai memiliki karakter permukiman yang dibangun diatas air. Teritori yang tidak jelas karena rumah yang didirikan berada diatas air merupakan alasan pemilik rumah membentuk suatu penanda atau batasan teritori rumahnya. Berdasarkan alasan tersebut dibentuklah teritori teras yang disesuaikan dengan kebutuhan dan mendukung aktivitas dalam teras. Permukiman kampung Bansir yang merupakan permukiman multi etnis dan berada di pesisir sungai, meciptakan pola perilaku yang khas dan dipengaruhi oleh keberadaan sungai Kapuas. Sehingga menciptakan karakteristik setting-setting tipe teras yang sama, namun memiliki fungsi teras yang berbeda. Penelitian ini hanya membahas khusus terciptanya setting teritori teras yang dipengaruhi kebiasaan atau perilaku pemilik rumah dan peruntukan teras sebagai ruang aktivitas tambahan. Dari hasil penelitian ini menghasilkan data mengenai karakteristik tipe setting teritori teras di pesisir sungai kampung Bansir.
\end{abstract}

Kata kunci: setting, tipe, teritori teras

\begin{abstract}
The terrace is an additional space that serves to accommodate the additional residents. A flexible use of the terrace is one of the reasons for the formation of terraces. Territory patio can be created from the occupant behavior patterns that have activities in the patio repetitive and constant. The research location is at Bansir Laut village, sub-district of southeast Pontianak, West Kalimantan. Bansir village settlements topology which is a riverside settlement has the character of settlements built on the water. Territories that are not clearly established because the house is above the water is the reason homeowners form a boundary marker or their home territory. Based on these reasons, established territory of terrace tailored to the needs and support the activities of the terrace. Thus, creating the same characteristic of the porch/terrace setting, with a different function. This research only discusses the creation of setting that influenced by the habits or behaviors from the homeowners and the allocation of the terrace as an additional activity space. From the results of this study, it generates data on the characteristics of the territory setting type of the terraces at the river Bansir village.
\end{abstract}




\section{Pendahuluan}

Teritorial merupakan suatu pola tingkah laku yang berhubungan dengan kepemilikan atau hak seseorang atau kelompok orang atas personalisasi dan juga merupakan pertahanan terhadap gangguan dari luar. Pembentukan kawasan teritorial adalah mekanisme perilaku untuk mencapai privasi tertentu. Kalau mekanisme ruang personal tidak memperlihatkan dengan jelas batas-batasan antar diri dengan orang lain, maka pada teritorialitas batas-batas tersebut nyata dengan tempat yang relatif tetap.

Bagian fungsi hunian yang berada sebagai teritorilitas ruang perantara lingkungan luar dan hunian ialah teras. Teras merupakan ruang terluar dari sebuah hunian yang biasa ditandai dengan adanya perkerasan lantai atau diberi penanda batas teritori (pagar). Teras juga disebut sebagai ruang transisi yang multifungsi, tergantung sang pemilik rumah menghendaki kegiatan yang berlangsung diteras.

Teras yang disetting oleh penduduk Bansir Laut beragam jenis serta peruntukan kegiatan yang ditampung. Masing-masing rumah memiliki teras yang berbeda-beda antara rumah satu dan yang lainnya. Perbedaan pembentukan teras juga berbeda antara rumah yang menghadap depan sungai dan yang membelakangi sungai. Sehingga jarang sekali bentukan rumah yang mirip dengan rumah tetanggannya.

Teras yang pada umumnya digunakan sebagai ruang penerimaan tamu yang tidak dikenal berkembang menjadi teras yang fungsional. Teras yang dapat digunakan sebagai tempat berjualan, ruang beristirahat, tempat pengepul kerajinan, atau tempat berkumpulnya suatu keluarga pada saat sore hari. Sehingga jenis setting teritori teras yang dihasilkan oleh aktivitas pemilik rumah sangat menarik untuk diteliti.

\section{Kajian Literatur}

\section{Definisi Kajian}

\section{Perilaku}

Perilaku (pe-ri-la-ku) adalah tanggapan atau reaksi individu terhadap rangsangan atau lingkungan (Kamus Besar Bahasa Indonesia:Edisi III). Kata perilaku sendiri dapat merujuk pada aksi dari manusia, berkaitan dengan semua aktivis manusia secara fisik; berupa interaksi manusia dengan sesamanya ataupun dengan lingkungan fisiknya.

Perilaku menurut Joyce Marsella Laurens (2004) mempunyai ciri-ciri sebagai berikut:

- $\quad$ Perilaku adalah kasatmata dan penyebab terjadinya perilaku secara langsung mungkin tidak dapat diamati.

- $\quad$ Perilaku mengenal berbagai tingkatan yaitu perilaku sederhana dan stereotip

- Perilaku bervariasi dengan klasifikasi: kognitif, afektif dan psikomotorik yang menunjuk pada sifat rasional, emosional, dan gerakan fisik dalam berperilaku.Perilaku bias disadari dan juga tidak disadari.

Menurut Roger Barker, seting perilaku (behavior setting) adalah konsep kunci bagi analisis perilaku manusia dalam arsitektur. Secara sederhana behavior setting dapat diartikan sebagai suatu interaksi antara suatu kegiatan dengan tempat yang spesifik.

Behavior setting didefinisikan sebagai suatu kombinasi yang stabil antara

aktivitas, tempat, dan kriteria berikut, menurut Barker 1968 dalam Joyce 2005 : 175 :

- Terdapat suatu aktifitas yang berulang berupa suatu pola perilaku

- Dengan tata lingkungan tertentu

- Membentuk suatu hubungan yang sama antar keduanya

- Dilakukan pada periode waktu tertentu. 
Setiap pelaku kegiatan akan menempati setting yang berbeda, sesuai dengan karakter kegiatannya. Batas behavior setting dapat berupa batas fisik, batas administrasi atau batas simbolik.Penentuan jenis batas ini tergantung dari pemisahan yang dibutuhkan antara beberapa behavior setting.

\section{Teritorialitas}

Holahan dalam Iskandar (1990), mengungkapkan bahwa teritorialitas adalah suatu tingkah laku yang diasosiasikan pemilikan atau tempat yang ditempatinya atau area yang sering melibatkan ciri pemilikannya dan pertahanan dari serangan orang lain.

Teritori merupakan suatu pembentukan wilayah geografis untuk mencapai privasi yang optimal. Dalam kaitannya dengan usaha memperoleh privasi adalah menyusun kembali setting fisik atau pindah ke lokasi lain. Penyusunan kembali setting dapat dilakukan dengan pembuatan teritori yang diwujudkan seperti membuat pagar, membuat 'tanda kepemilikan' atau marking pada lokasi-lokasi di sungai, pegunungan ataupun di bukit (Helmi, 1994).

\section{Penanda Teritori}

Edney (1974) mendefinisikan teritorialitas sebagai sesuatu yang berkaitan dengan pertahanan, tanda, kepemilikan. Fisher mengatakan bahwa kepemilikan dalam teritorialitas ditentukan oleh persepsi orang yang bersangkutan. Penanda teritori ditujukan untuk mempertahankan hak seseorang dalam teritori publik dan meminimalisir berbagai bentuk pelanggaran teritori. Penandaan bisa terjadi tanpa kesadaran akan batas wilayah. Dalam penelitian ini, yang dimaksud dengan penanda teritori dalam rumusan masalah satu adalah pagar pembatas rumah. Pagar pembatas rumah dibangun masyarakat setempat sebagai penanda batas wilayah tempat tinggal dan meningkatkan rasa aman serta mengurangi kriminalitas dalam lingkungan perumahan tersebut.

\section{Pemahaman Teori}

\section{Teritorialitas dan Perilaku}

Altman (1980) membagi teritorialitas berdasarkan derajat privasi, afiliasi ${ }^{1}$, dan kemungkinan pencapaian menjadi tiga; teritori primer, teritori sekunder, dan teritori publik:

a) Teritori primer, adalah tempat-tempat yang sangat pribadi sifatnya, hanya boleh dimasuki oleh orang-orang yang sudah sangat akrab atau yang sudah mendapatkan izin khusus. Jenis teritori ini dimiliki serta dipergunakan secara khusus bagi pemiliknya. Pelanggaran terhadap teritori utama ini akan mengakibatkan timbulnya perlawanan dari pemiliknya dan ketidakmampuan untuk mempertahankan teritori ini akan mengakibatkan masalah yang serius terhadap aspek psikologis pemiliknya, yaitu dalam hal harga diri dan identitasnya.

Contoh : pekarangan, ruang tidur, ruang kerja.

b) Teritori sekunder, adalah tempat-tempat yang dimiliki bersama oleh sejumlah orang yang sudah cukup saling mengenal. Jenis teritori ini lebih longgar pemakaiannya dan pengontrolan oleh perorangan. Sifat territorial sekunder adalah semi-publik.

Contoh : toilet, sirkulasi lalu intas di dalam kantor

c) Teritori publik, adalah tempat-tempat yang terbuka untuk umum. teritorial umum dapat digunakan secara sementara dalam jangka waktu lama maupun singkat. Pada prinsipnya setiap orang diperkenankan untuk berada di tempat tersebut.

Contoh : gedung bioskop, ruang kuliah, pusat perbelanjaan dll.

\footnotetext{
${ }^{1}$ Afiliasi merupakan salah satu cara mengembangkan bisnis dengan cara memanfaatkan sosialisasi yang secara terarah dilakukan oleh individu, badan usaha atau organisasi dan kedua belah pihak akan mendapatkan keuntungan seperti yang sudah disepakati bersama (Sadhily, 1996).
} 
Laurens (2001), menyimpulkan teritorialitas berfungsi sebagai proses sentral dalam personalisasi, agresi, dominasi, koordinasi dan kontrol.

1. Personalisasi dan penandaan.

Personalisasi dan penandaan seperti memberi nama, tanda atau menempatkan di lokasi strategis, bisa terjadi tanpa kesadaran teritorialitas. Seperti membuat pagar batas, memberi nama kepemilikan. Penandaan juga dipakai untuk mempertahankan haknya di teritori publik, seperti kursi di ruang publik atau naungan.

\section{Agresi}

Pertahanan dengan kekerasan yang dilakukan seseorang akan semakin keras bila terjadi pelanggaran di teritori primernya dibandingkan dengan pelanggaran yang terjadi diruang publik. Agresi biasa terjadi disebabkan karena batas teritori tidak jelas.

3. Dominasi dan Kontrol.

Dominasi dan kontrol umumnya banyak terjadi di teritori primer. Kemampuan suatu tatanan ruang untuk menawarkan privasi melalui kontrol teritori menjadi penting.

4. Teritori sebagai perisai perlindungan.

Banyak individu atau kelompok rela melakukan tindakan agresi demi melindungi teritorinya, maka kelihatannya teritori tersebut memiliki beberapa keuntungan atau hal yang dianggap penting. Kebenaran dari kalimat "Home Sweet Home", telah diuji dalam berbagai eksperimen. Penelitian mengenai teritori primer, skunder, dan publik menunjukkan, bahwa orang cenderung merasa memiliki kontrol terbesar pada teritori primer, dibanding dengan teritori sekunder maupun teritori publik. Ketika individu mempresepsikan daerah teritorinya sebagai daerah kekuasaannya, itu berarti mempunyai kemungkinan untuk mencegah segala kondisi ketidak nyamanan terhadap teritorinya.

\section{Teori Level Adaptasi}

Teori ini pada dasarnya sama dengan teori beban lingkungan. Menurut teori ini, stimulasi level yang rendah maupun level tinggi mempunyai akibat negatif bagi perilaku. Level stimulasi yang optimal adalah yang mampu mencapai perilaku yang optimal pula. Vetich dan Arkellin ( dalam Helmi, 1999). Dengan demikian dalam teori ini dikenal perbedaan individu dalam level adaptasi.

Adaptasi dilakukan ketika terjadi suatu disonansi dalam suatu sistem, artinya ketika keseimbangan antara interaksi manusia dengan lingkungan, tuntutan lingkungan yang berlebih atau kebutuhan yang tidak sesuai dengan situasi lingkungan. Dalam hal ini adaptasi merupakan suatu proses modifikasi kehadiran stimulus yang berkelanjutan. Semakin sering stimulus hadir, maka akan terjadi pembiasaan secara fisik yang disebut sebagai habituasi dan terjadi pembiasaan secara fisik yang disebut adaptasi. Menurut Helmi (1995), bahwa ketika seorang mengalami proses adaptasi, perilakunya diwarnai kontradiksi antara toleransi terhadap kondisi yang menekan dan perasaan ketidakpuasan sehingga orang akan melakukan proses pemilihan dengan dasar pertimbangan yang rasional antara lain meminimalkan biaya.

\section{Teritorialitas Dalam Desain Arsitektur}

Laurens (2001), mengungkapkan penerapan teritorialitas dalam desain mengacu pada pola tingkah laku manusia yang berkaitan dengan teritorialitas sehingga dapat mengurangi agresi, meningkatkan kontrol, dan membangkitkan rasa tertib dan aman. Semakin banyak sebuah desain mampu menyediakan teritori primer bagi penghuninya, maka desain itu akan semakin baik dalam memenuhi kebutuhan penggunanya.

1. Publik dan Privat 
Ruang publik adalah area yang terbuka. Ruang ini dapat dicapai oleh siapa saja pada waktu kapan saja dan tanggung jawab pemeliharaannya bersifat kolektif ${ }^{2}$. Ruang privat adalah area yang aksesibilitasnya ditentukan oleh seseorang atau sekelompok orang dengan tanggung jawab pemeliharaannya ditanggung bersama.

2. Ruang Peralihan

Daerah peralihan dibuat sebagi penghubung berbagai teritori yang memiliki perbedaan sifat. Area pintu masuk sekolah merupakan daerah transisi. Pada aera transisi, gugatan teritori individual dan kolektif dapat saling tumpang tindih. Untuk menghindari terjadinya konflik, maka diperlukan kesepakatan. Keberhasilan ruang peralihan dalam membentuk ruang komunal yang baik adalah dengan memberi kontribusi demi kenyamanan lingkungan.

\section{Variabel/Komponen Dalam Ruang}

Variabel atau komponen dalam ruang ialah elemen-elemen penyusun terbentuknya sebuah ruang yang dipengaruhi atau mempengaruhi psikologi dan aktivitas pelaku.

a. Ukuran dan Bentuk / Elemen Fix

Variabel ini bersifat fix / tetap atau sebagai pembentuk batasan fisik sebuah ruang, misal: ukuran luas ruang, bentuk dinding dan atap, besaran kolom-balok, dan jenis bahan/material. Perancangan ruang dalam hal ukuran dan bentuk harus disesuaikan dengan fungsi yang akan diwadahi.

b. Perabot dan Layout / Elemen Semi Fix

Variabel ini bersifat semi-fix (bersifat semi permanen). Dapat menjadi batas fisik namun masih dapat berubah, berpindah, atau ditata. Elemen fix dapat berupa perabot seperti meja dan kursi. Perabot sebagai variabel tak tergantung dari ruang, dan penggunaanya dapat mempengaruhi persepsi dan penilaian orang tentang ruang.

c. Warna Ruang / Elemen non-Fix

Variabel ini bersifat non-fix (bersifat tidak tetap). Elemen ini tidak menjadi penentu batas fisik, dan tidak mengikat ruang dapat dirubah dan diganti, namun bisa memberi efek pengaruh terhadap ruang.

d. Cahaya, Suara dan Temperatur / Elemen non-Fix

Tiga unsur lingkungan ini juga mempunyai pengaruh terhadap kualitas dan kondisi ruang serta perilaku pemakainya. Pencahayaan ruang difungsikan untuk memenuhi kebutuhan ruang akan cahaya dan estetika, kualitas cahaya pada sebuah ruang dapat mepengaruhi kondisi psikologi seseorang. Suara berhubungan dengan tingkat kebisisngan dalam sebuah ruang, jika desibelnya terlalu keras maka akan berdampak buruk bagi pengguna ruang. Temperatur berhubungan dengan kenyamanan pengguna ruang. Ruang yang memiliki sedikit bukaan akan menimbulkan temperatur yang panas dan akan menimbulkan ketidaknyamanan pengguna yang beraktivitas didalamnya.

\section{Behavior Setting dalam Desain Arsitektur}

Behavior setting yang baik adalah yang sesuai atau pas dengan struktur perilaku penggunanya. Behavior setting memberi dasar yang lebih luas dalam mepertimbangkan lingkungan daripada hanya semata-mata tata guna lahan, tipe bangunan, dan tipe ruang secara fisik. Edward T. Hall (1966), mengidentifikasi tiga tipe dasar pola ruang, antara lain;

1. Ruang Berbatas Tetap (fixed-feature space)

Ruang berbatas tetap dilingkupi oleh pembatas yang relatif tetap dan tidak mudah digeser, seperti dinding masif, jendela, pintu, atau lantai.

\footnotetext{
${ }^{2}$ Kolektif adalah perihal yang merupakan gabungan bebeberapa kompisisi / tercipta dari perihal yang dilakukan secara bersamaan (Kamus Besar Bahasa Indonesia, edisi III).
} 
2. Ruang Berbatas Semitetap (semifixed-feature space)

Ruang berbatas semi tetap adalah ruang yang pembatasnya bisa berpindah. Contohnya adalah ruang-ruang pameran yang dibatasi partisi yang dapat dipidahkan sesuai dengan kebutuhan setting.

3. Ruang Informal

Ruang informal adalah ruang yang terbentuk dalam waktu yang singkat, seperti ruang yang terbentuk ketika dua atau lebih orang berkumpul. Ruang ini bersifat tidak tetap dan terjadi diluar kesadaran orang yang bersangkutan.

Rapoport (1996) dalam Laurens (2001:149) mengidentifikasikan lima aspek budaya yang tercermin dalam desain sebuah rumah, yaitu: cara menjalankan aktivitas dasar, struktur keluarga, peran gender, sikap terhadap privasi dan proses sosial.

\section{Metodologi Penelitian \\ Objek Penelitian}

Penelitian ini dilakukan di permukiman Kampung Bansir pesisir sungai Kapuas, kecamatan Pontianak Tenggara, Kalimantan Barat. Objek yang diteliti ialah enam Bangunan yang tersebar di tepi sungai daerah tersebut. Fokus amatan yang diteliti adalah setting teritori teras bangunan.

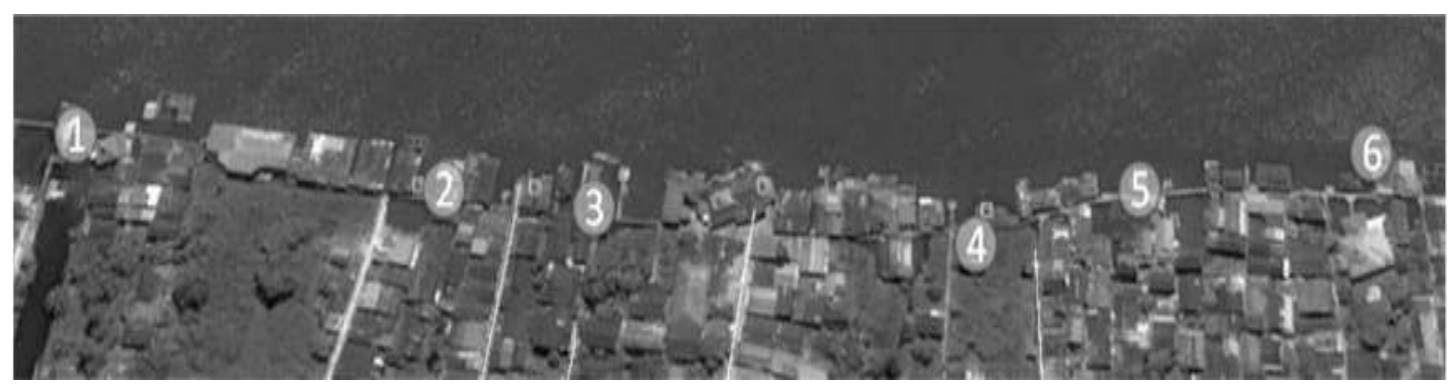

Gambar 1. Lokasi bangunan/ rumah di pesisir kampung Bansir

Sumber : Analisa Penulis (2015)

\section{Tahap-Tahap Penelitian}

Tahap-tahap penelitian yang akan dijabarkan dan dibahas ialah rangkaian proses penelitian berupa langkah-langkah yang sesuai dengan urutan kegiatan/proses penelitian. Patokan dalam meneliti dengan menjadikan teori sebagai batasan penelitian.

\section{Place-centered mapping}

Teknik ini digunakan untuk mengetahui bagaimana manusia atau sekelompok manusia memanfaatkan, menggunakan atau mengakomodasikan perilakunya dalam suatu situasi waktu dan tempat yang tertentu. Dengan kata lain, perhatian dari teknik ini adalah satu tempat yang spesifik baik kecil atau pun besar.

Dalam proses place-centered map membutuhkan peta dasar yang sudah dibuat untuk mengamati objek penelitian dan kemudian membuat daftar perilaku yang diamati serta menentukan simbol atau tanda sketsa perilaku. Kemudian data kolektif berdasarkan perilaku di tempat objek penelitian di analisis untuk mendapatkan kesimpulan kecenderungan perilaku. Langkah-langkah yang dilakukan pada teknik ini adalah:

1. Menentukan tempat/ruang yang akan diamati (dijadikan objek penelitian)

2. Menentukan waktu pengamatan

3. Mengamati aktivitas yang terjadi dalam tempat amatan

4. Mencatat aktivitas yang terbentuk di tempat amatan

5. Membuat dominasi kegiatan berdasarkan waktu 


\section{Time Budged}

Menurut Michelson dan Reed dalam Joyce (2005 : 184), dalam behavior setting juga dilakukan analisis dengan Time Budget yaitu memungkinkan orang menguraikan/mengkomposisikan suatu aktivitas sehari-hari, aktivitas mingguan atau musiman kedalam seperangkat behavior setting yang meliputi hari kerja atau gaya hidup. Informasi ini meliputi hal - hal sebagai berikut :

- Jumlah waktu yang dialokasikan untuk kegiatan tertentu dengan variasi waktu dalam sehari, seminggu atau semusim.

- Frekuensi dari aktifitas dan jenis aktivitas yang dilakukan

- Pola tipikal dari aktivitas yang dilakukan

\section{Teknik Pengumpulan Data}

Teknik pengumpulan data pada penelitian ini dapat dilakukan dengan beberapa cara yang terkait dengan judul penelitian. Teknik yang dapat dilakukan dapat berupa teknik wawancara untuk mendapatkan informasi langsung dari informan yang terkait dengan objek penelitian. Selain itu juga digunakan teknik observasi untuk melakukan pengamatan langsung terhadap objek.

Variabel penelitian adalah setiap hal dalam suatu penelitian yang datanya ingin diperoleh. Dinamakan variabel karena nilai dari data tersebut beragam. Variabel yang digunakan dalam penelitian ini berupa:

1. Pelaku

2. Waktu (intensitas)

3. Setting (tempat. elemen fix, non fix, semi fix)

4. Aktivitas (kegiatan)

\section{Teknik Analisis Data}

Teknik analisa data yang digunakan dalam penelitian ini ialah penelitian bersifat kualitatif. Moleong (1991: 103) mengatakan bahwa prinsip penelitian kualitatif adalah menemukan teori dan data. Peranan teori baru atau verifikasi teori baru akan tampak sewaktu analisis data ini mulai dilakukan. Tahapan analisis data merupakan satu bagian yang tidak terpisahkan dengan tahapan-tahapan lainnya. Data primer dan sekunder dianalisis secara kualitatif, melalui verstehen atau interpretasi atau juga disebut dengan tafsir.

Metode untuk menunjang penelitian kualitatif ini juga dilakukan dengan menerapkan metode deskriptif dan metode korelasi untuk dapat menyimpulkan data analisis menjadi satu kesimpulan.

\section{Metode Deskriptif}

Menurut Whitney (1960), metode deskriptif adalah pencarian fakta dengan interpretasi yang tepat. Penelitian deskriptif mempelajari masalah-masalah dalam masyarakat, serta tata cara yang berlaku salam masyarakat serta situasi-situasi tertentu, termasuk tentang hubungan kegiatan, sikap, pandangan, serta proses-proses yang sedang berlangsung dan pengaruh dari suatu fenomena. Penelitian deskriptif adalah metode penelitian yang berusaha menggambarkan objek atau subjek yang diteliti sesuai dengan apa adanya (Best, 1982: 119). ${ }^{3}$

\section{Metode Korelasi}

\footnotetext{
3 Alfa Rizki, Metode Penelitin Deskriptif (http://alfaruq2010.blogspot.com). Diunduh pada tanggal 17 November, 2015, pukul 21:30 wib.
} 
Metode Korelasi adalah suatu penelitian yang dilakukan untuk menggambarkan dua atau lebih fakta-fakta dan sifat-sifat objek yang di teliti.

\section{Hasil dan Pembahasan \\ Data Eksisting}

Bangunan (teras 1) ini merupakan sebuah warung makan yang biasa beroperasi pada siang dan sore hari. Letaknya menghadap langsung ke arah sungai Kapuas menawarkan view yang menarik dan lapang. Warung ini ramai dikunjungi oleh ibu-ibu untuk bersosialisasi sehabis melakukan pekerjaan rumah. Ukuran warung ini tidak terlalu besar, yaitu sekitar 7x3 $m^{2}$. Struktur utama bangunan menggunakan struktur kayu dengan pagar atau dinding setengah berbahan papan bekas. Tata perabot diletakan secara tersusun dengan meja makan disisi-sisi bangunan dan satu meja ditengah. Kebanyakan perabot untuk melengkapi fungsi bangunan pada umumnya terbuat dari kayu yang dicat maupun tanpa dicat.
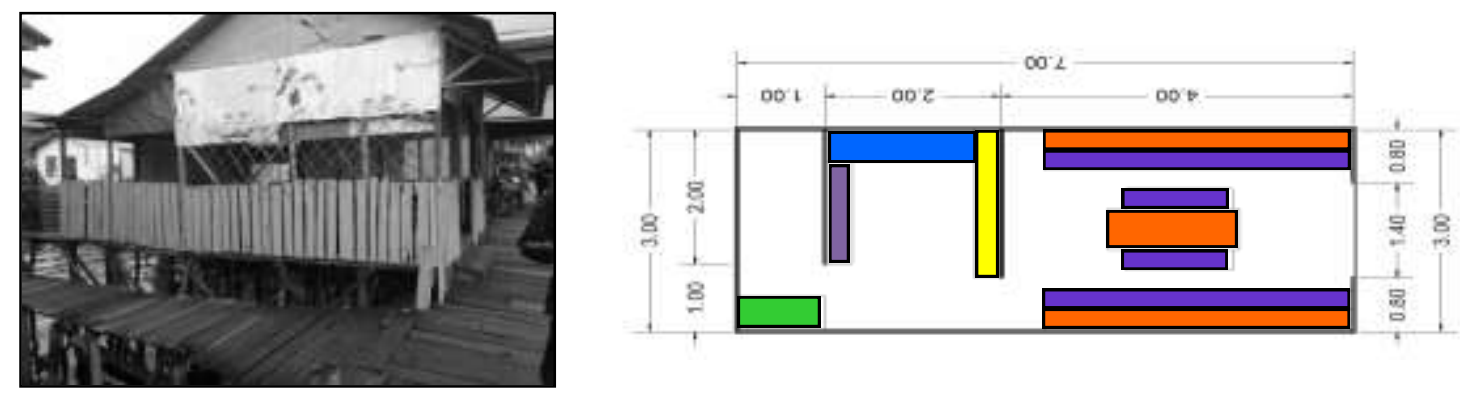

Gambar 2: Kondisi dan setting teras 1

Sumber : Analisa Penulis (2016)
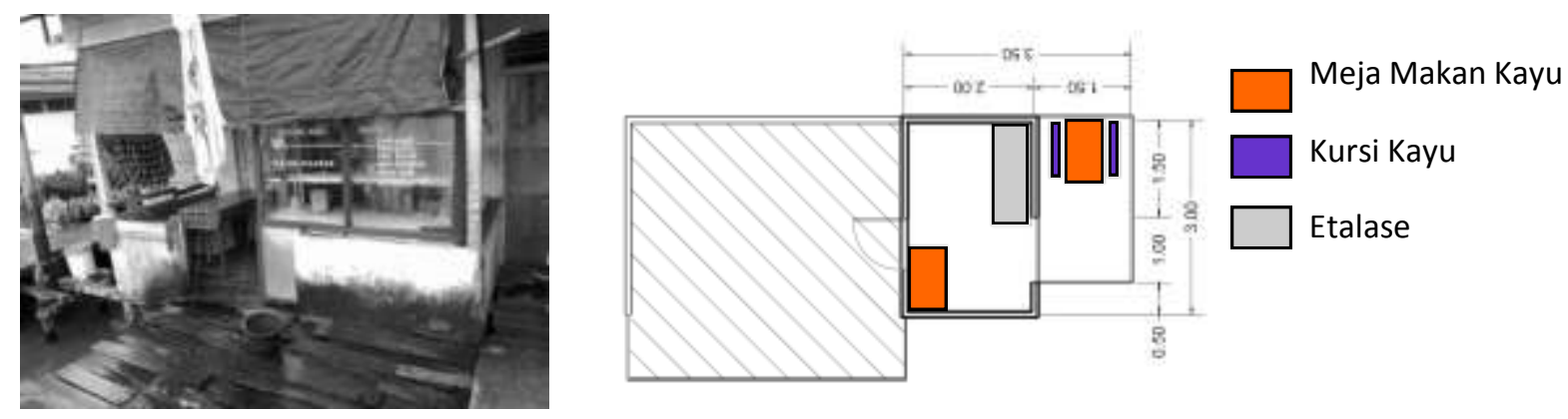

Gambar 3: Kondisi dan setting teras 2

Sumber : Analisa Penulis (2016)

Rumah ini (teras 2) mengubah teras sebagai ruang untuk menyajikan makanan siap saji sehingga tatanan perabot dibuat untuk mendukung kegiatan tersebut. Ukuran teras $2 \times 3 \mathrm{~m}^{2}$ sehingga tampak kecil untuk meletakan perabot-perabot pendukung. Di depan teras juga terdapat lantai kayu mirip gertak yang berfungsi untuk menyambungkan antara teras dan gertak utama. 

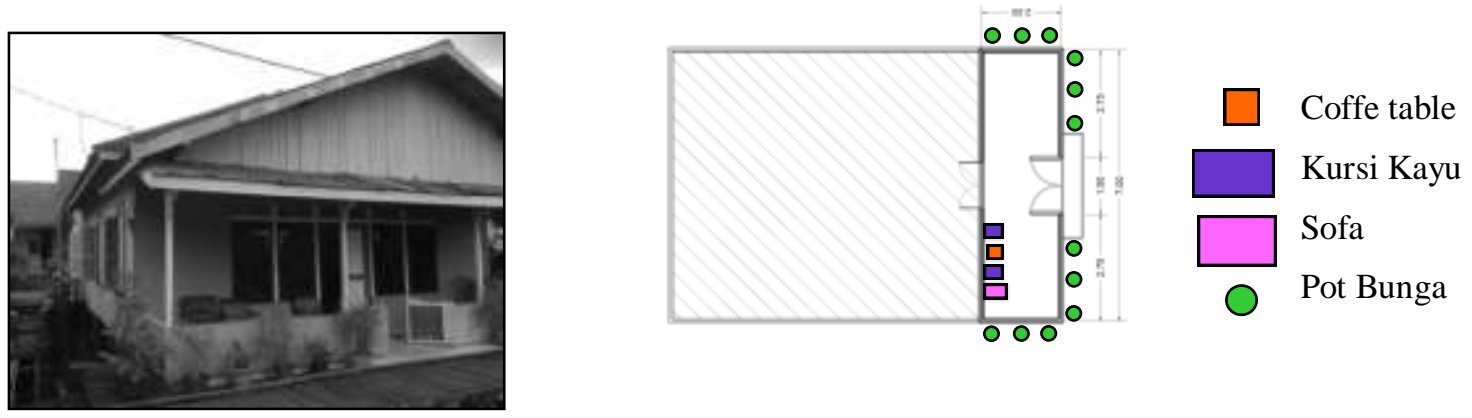

Gambar 4: Kondisi dan setting teras 3

Sumber : Analisa Penulis (2016)

Rumah ketiga merupakan rumah kepala RT di salah satu RT di Bansir Laut. Pembentukan teras digunakan sebagai pendukung aktivitas pekerjaan dari jabatan si pemilik rumah. Setting yang diberikan juga diperhatikan dari segi keindahan serta kenyamanan bagi pemilik rumah dan lingkungannya. Layout dan elemen yang digunakan sudah tergolong lebih modern dibanding dengan contoh rumah yang lain di bansir laut. Penambahan pintu masuk kecil sebagai pengganti pagar geser dan menambah kecantikan bangunan. Penggunan keramik sebagai penutup finishing lantai membuat kesan bersih dan rapi. Elemen pendukung untuk setting teras ialah pintu masuk yang dibuat bergaya western yang dikontraskan dengan warna pagar. Elemen pendukung lainnya ialah tanaman diletakan dalam pot dan disusun selang-seling berdasarkan jenis tanaman untuk memberikan variasi visual.
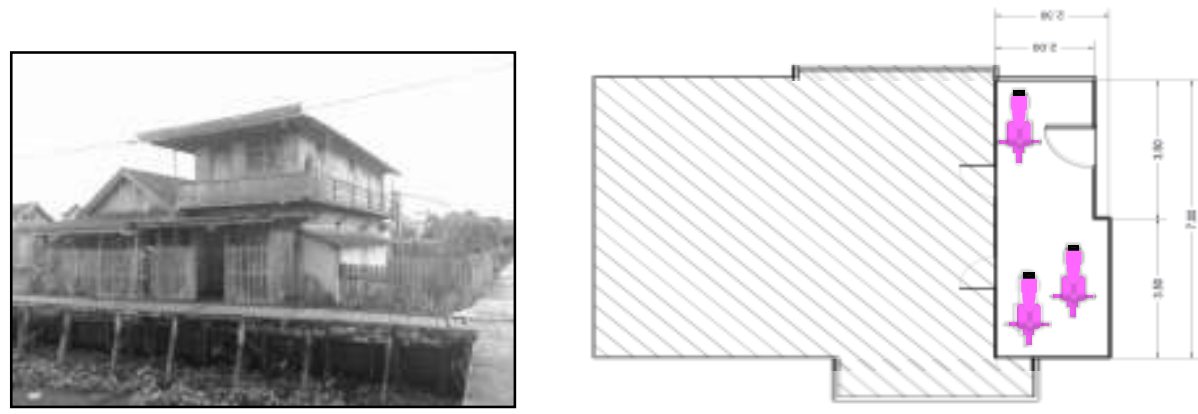

Gambar 5: Kondisi dan setting teras 4

Sumber : Analisa Penulis (2016)

Rumah ke-empat merupakan salah satu rumah lama yang ada di kelurahan bansir laut yang menghadap kearah sungai Kapuas. Bangunan ini telah beralih fungsi sebagai rumah kost dengan beberapa tambahan perubahan setting termasuk terasnya. Teras dirumah ini berfungsi sebagai pendukung kegiatan atau ruang pendukung dari fungsi bangunan kost, yaitu garasi tempat menyimpan kendaraan penghuni kost. 

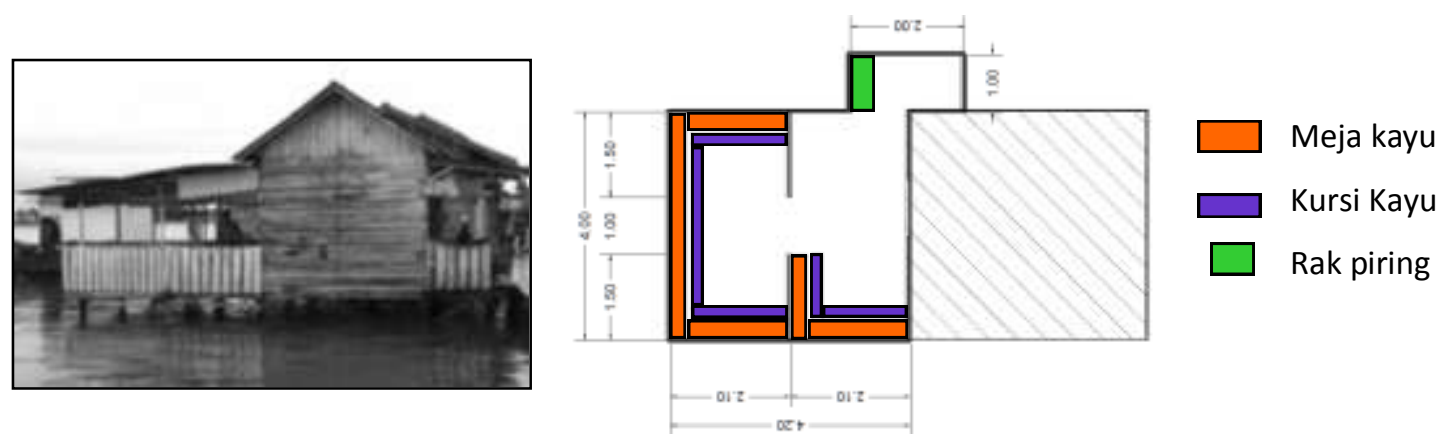

Gambar 6: Kondisi dan setting teras 5

Sumber : Analisa Penulis (2016)

Rumah ini (teras 5) merupakan sebuah rumah yang digunakan sebagai rumah makan atau warung. Bangunan ini tepat berada di sebelah sungai dengan muka bangunan membelakangi sungai. Ruang teras yang digunakan sebagai ruang makan terletak dibelakang bangunan agar pengunjung dapat menikmati Susana makan menghadap sungai. Elemen penyusun bangunan/ rumah ini sebagian besar terbuat dari papan/ kayu dengan finishing cat. Peletakan perabot menyesuaikan dan memanfaatkan peletakan bangunan terhadap view sungai. Meja makan dibuat menghadap kearah sungai dengan dibagian tengah ruang kosong untuk sirkulasi pergerakan.
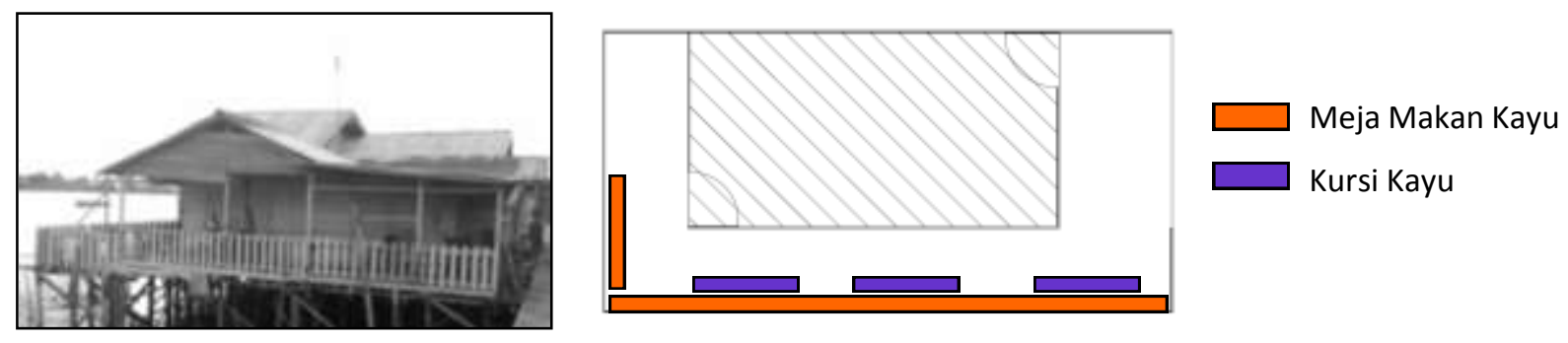

Gambar 7: Kondisi dan setting teras 6 Sumber : Analisa Penulis (2016) 
Bangunan ini merupakan rumah sekaligus tempat berjualan/ rumah makan yang beroperasi pada saat-saat tertentu sehingga bangunan ini memiliki fungsi lain sebagai tempat penyimpanan bahan baku pembuatan toping caping dan juga sebagai gudang sebelum hasil kerajinan dipasarkan.

\section{Pembahasan}

Tabel 1: Analisa karakteristik setting teritori teras

\begin{tabular}{|c|c|c|c|c|c|}
\hline \multirow{2}{*}{$\begin{array}{l}\text { Kode } \\
\text { Teras }\end{array}$} & \multirow{2}{*}{$\begin{array}{l}\text { Sifat } \\
\text { Teras }\end{array}$} & \multicolumn{2}{|c|}{$\begin{array}{c}\text { Fisik Teras } \\
\end{array}$} & \multicolumn{2}{|c|}{ Aktivitas / Perilaku } \\
\hline & & $\begin{array}{l}\text { Jenis Pembatas } \\
\text { teras }\end{array}$ & $\begin{array}{c}\text { Setting } \\
\text { Teras }\end{array}$ & $\begin{array}{l}\text { Kegiatan yang } \\
\text { Berlangsung }\end{array}$ & $\begin{array}{c}\text { Orientasi berlangsungnya } \\
\text { aktivitas }\end{array}$ \\
\hline Teras 1 & Umum & Semi permanen & Sentral & $\begin{array}{l}\text { Makan, } \\
\text { berbincang- } \\
\text { bincang, duduk- } \\
\text { duduk. }\end{array}$ & $\begin{array}{l}\text { Sebagian besar menghadap ke } \\
\text { sungai, namun ada yang } \\
\text { menghadap sentral. }\end{array}$ \\
\hline Teras 2 & Umum & Permanen & Sisi & $\begin{array}{l}\text { Menyajikan } \\
\text { makanan, makan, } \\
\text { berbincang- } \\
\text { bincang, duduk- } \\
\text { duduk. }\end{array}$ & $\begin{array}{l}\text { Untuk pengunjung menghadap } \\
\text { sentral meja makan. } \\
\text { Sedangkan pemilik rumah } \\
\text { menghadap kearah sungai/ } \\
\text { depan }\end{array}$ \\
\hline Teras 3 & Umum & Permanen & Sisi & $\begin{array}{l}\text { Duduk-duduk, } \\
\text { berbincang- } \\
\text { bincang, bersantai }\end{array}$ & $\begin{array}{l}\text { Berkumpul di area perabot } \\
\text { teras (kursi) dan menghadap } \\
\text { arah sungai }\end{array}$ \\
\hline Teras 4 & Privat & Semi permanen & Sentral & $\begin{array}{l}\text { Aktivitas servis } \\
\text { (garasi) }\end{array}$ & $\begin{array}{l}\text { Tidak berpola, karena } \\
\text { penggunaan teras bersifat } \\
\text { servis. }\end{array}$ \\
\hline Teras 5 & Umum & Semi permanen & Sisi & \multirow{2}{*}{$\begin{array}{l}\text { Makan, } \\
\text { berbincang- } \\
\text { bincang, duduk- } \\
\text { duduk, mencuci } \\
\text { piring }\end{array}$} & $\begin{array}{l}\text { Menyebar disi-sisi teras } \\
\text { menghadap bagian sungai. }\end{array}$ \\
\hline Teras 6 & Umum & Semi permanen & Sisi & & $\begin{array}{l}\text { Menyebar disi-sisi teras } \\
\text { menghadap bagian sungai. }\end{array}$ \\
\hline
\end{tabular}

Sumber : Analisa Penulis (2016)

Perubahan setting teritori teras juga terjadi di beberapa teras amatan. Penggunaan teras yang semakin berkembang dan kecendrungan perilaku masyarakat yang senang berbincang menghadap sungai, maka teritori teras mengalami perkembangan/ pelebaran kearah sungai seperti di teras 1,2 , dan 5 .

Terdapat pula fungsi teras umum yang memiliki zona privat yang hanya digunakan oleh pemilik atau penghuni rumah. Sekilas tampak ada garis khayal pemisah antara zona diteras untuk umum dan privat. Contoh teras yang terlihat adanya garis khayal pembeda zona terdapat pada teras 1,6 , dan 5 .

Tabel 2: Analisa karakteristik setting teritori teras 1-3

Perilaku tamu /orang lain yang berkunjung sering menghadap sungai sehingga dibentuk setting ruang yang

Teras 1 berorientasi menyebar. Setting teritori teras yang digunakan merupakan penggunaan pagar dan jaring yang membuat kaku ruang namun tetap terbuka.

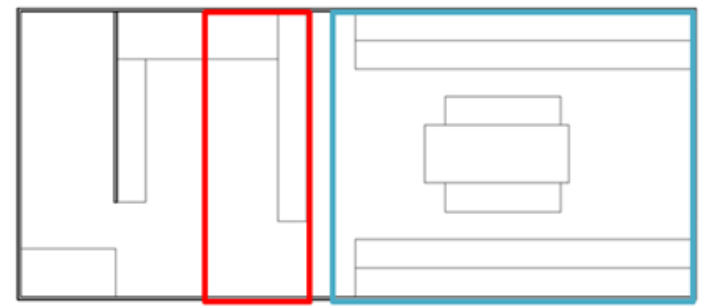


Sebagian besar kegiatan utama dari pemilik rumah adalh ruang yang dekat langsung dengan pintu utama. Maka, zona yang terhubung langsung dengan ruang utama adalah bagian teritori sipemillik rumah yang diletakan perabot-perabot pendukung. Sedangkan area depan teras yang merupakan perluasan dari ruang teras adalah sebagai teritori si tamu untuk makan.

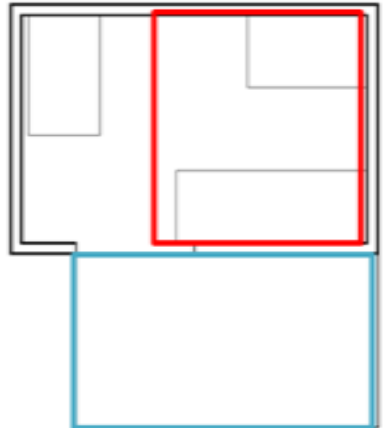

Setting teritori teras ini lebih sederhana, hanya menempatkan kursi kopi sebagai perabot tambahan yang disebabkan kebiasaan penghuni rumah yang senang mengobrol/ bersantai di sore hari. Teras ini juga digunakan sebagai ruang kumpul warga, jumlah

Teras 3 perabot yang tidak banyak memudahkan dalam menampung orang yang duduk melantai/ lesehan.

Penggunaan pagar yang rendah juga memberi kesan yang baik bagi pandangan tetangga, karena mencerminkan sifat keterbukaan dari si pemilik rumah.

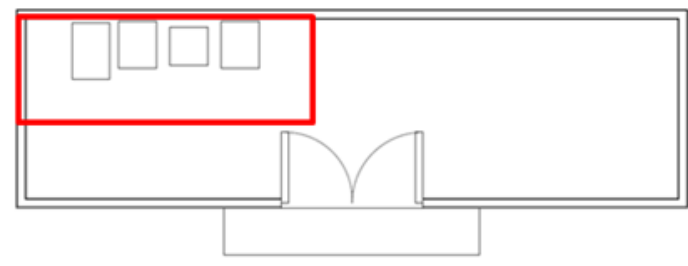

Sumber : Analisa Penulis (2016)

Tabel 3: Analisa karakteristik setting teritori teras 4-6

Untuk menjaga agar lingkungan rumah kost khusus wanita terasa

Teras aman, penggunaan pagar tinggi dipilih

4 sebagai penanda teritori rumah yang tegas dan tertutup. Teras dikelilingi pagar kayu yang tinggi dan rapat.

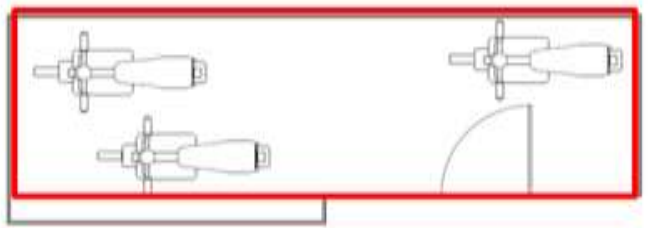

Setting teras yang berubah akibat perilaku pengunjung/ tamu yang sering makan sambil menghadap kearah sungai, sehingga terjadi posisi

Teras menyebar pada sisi teras. terbentuk

5 teritori teras pengunjung dibagian depan yang mencakup setengah besar teras. sedangkan teritori pemilik berada dekat dengan ruang servis (cuci) dibagian belakang.

Perubahan setting teras hampir sama dengan teras 5 , namun pergerakan pengunjung lebih tersebar kearah samping sehingga terbentuk

Teras setting tempat duduk menyamping

6 dan teritori pengunjung. Dibagian belakang yang ukuranya lebih sempit dan dekat dengan wc merupakan teritori pemilik/ penghuni rumah.karena tidak ada pengunjun/
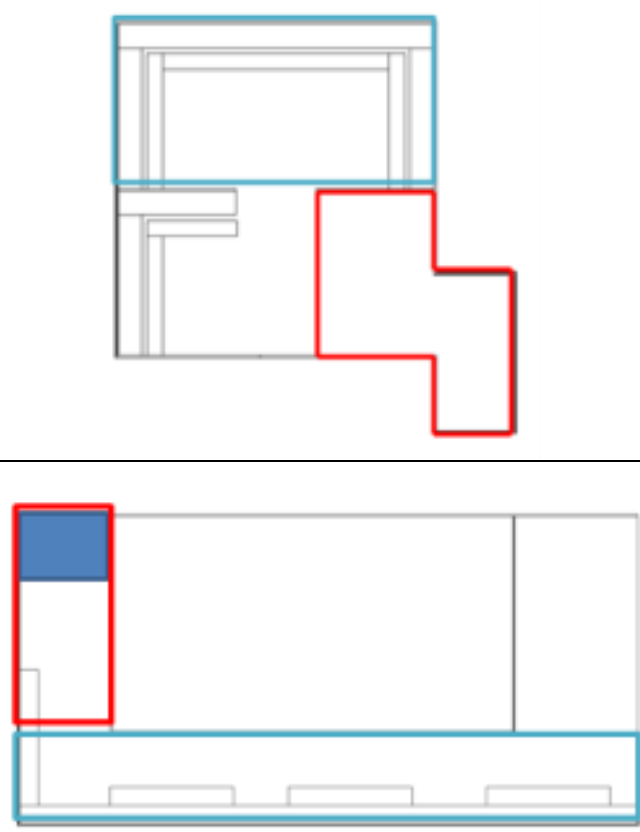
tamu yang mau duduk di sekitar

bagian tersebut.

Sumber : Analisa Penulis (2016)

\section{Kesimpulan}

Teras merupakan sebuah ruang yang tercipta sebagai wadah untuk melakukan aktivitas tambahan. Teras pada umumnya merupakan ruang transisi antara ruang dalam yang bersifat privat dan lingkungan luar. Teras juga merupaka suatu ruang yang menunjukan batas teritori dari sebuah rumah. Keberlangsungan teras tergantung atau terpengaruhi oleh 2 faktor utama, yaitu pelaku dan aktivitas.

Fungsi teras sangat beragam dikalangan masyarakat. Oleh karena itu, teras juga dikatakan sebagai ruang multifungsi. Teras tidak hanya dibutuhkan oleh rumah-rumah modern, namun teras sudah terbentuk dari permukiman zaman dahulu. Setting-setting teras pun yang dibentuk beragam, berdasarkan keinginan pelaku/ pemilik teras dan aktivitas yang diwadahinya.

Dalam studi kasus dilihat sejauh mana perilaku manusia menentukan setting teritori teras. Studi kasus dilakukan di permukiman pesisir kampung Bansir Laut, yang memiliki tatanan rumah yang dipengaruhi oleh keberadaan sungai Kapuas. Pada daerah ini dapat ditemukan tipe setting teritori teras beserta karakteristik yang ada pada setting tersebut.

Tabel 4: Tipe Setting Teritori Teras

\begin{tabular}{|c|c|c|c|c|}
\hline No. & Jenis Teras & Sifat Teras & Contoh & Ciri-ciri \\
\hline 1 & Teras Pribadi & Terbuka & & $\begin{array}{l}\text { Teras memiliki tinggi pagar } \\
\text { maksimal } 0.8 \mathrm{~m} \text { atau tidak memiliki } \\
\text { pagar pembatas teritori yang tegas } \\
\text { yang menandakan sifat keterbukaan } \\
\text { atau memudahkan akses dari orang } \\
\text { lain masuk ke teritori rumah tersebut. }\end{array}$ \\
\hline 2 & Teras Pribadi & Tertutup & & $\begin{array}{l}\text { Teras memiliki batasan teritori teras } \\
\text { yang tegas dan menutupi muka } \\
\text { bangunan. Tinggi pagar minimal } 1 \mathrm{~m} \\
\text { dengan akses masuk keteras } \\
\text { menggunakan pintu teras. Pagar dari } \\
\text { teras ini mengesankan tingkat privasi } \\
\text { atau ke protektifan yang tinggi dari si } \\
\text { pemilik rumah. Sehingga teras yang } \\
\text { dimunculkan seolah-olah sebagai } \\
\text { benteng. }\end{array}$ \\
\hline 3 & Teras Umum & Terbuka & & $\begin{array}{l}\text { Jenis teras ini mirip dengan jenis } \\
\text { teras } 1 \text {, namun peruntukan teras yang } \\
\text { melakukan kegiatan umum } \\
\text { didalamnya. Akses dari teras yang } \\
\text { dapat diakses langsung tanpa harus } \\
\text { masuk ke ruang transisi dari } \\
\text { bangunan. }\end{array}$ \\
\hline
\end{tabular}


Teras Umum Tertutup

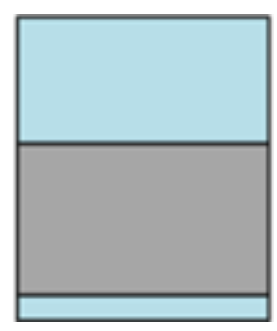

Teras ini tidak tampak dari luar sehingga perlu masuk ke suatu ruang untuk dapat mengaksesnya. Kebanyakan teras ini berada dibelakang bangunan dan mengarah langsung ke sungai Kapuas, sedangkan muka bangunan membelakangi sungai.

\section{Sumber : Analisa Penulis (2016)}

Berikut beberapa karakter teras yang teradapat di kampung Bansir berdasarkan hasil analisa pada bab 4 :

Karakter pertama, setting teras di permukiman Bansir Laut memiliki susunan yang cenderung menghadap kearah sungai. Penyebabnya adalah kebiasaan masyarakat yang senang berbincang-bincang sambil menikmati pemandangan sungai. Hembusan angin yang langsung menerpa badan akan membuat orang terasa nyaman dan segar. Sehingga, orang betah untuk berlama-lama berada dilokasi.

Karakter kedua, adanya ruang teras yang memiliki garis khayal sebagai pembatas teras umum dan pribadi meski dalam teras yang sama. Seperti yang dijabarkan pada bagian teras 1 , 6 dan 5. Pembedaan ini tidak tertulis atau jelas keberadaanya, namun dapat dirasakan secara letak dan setting yang dibentuk.

Karakter ketiga, sebagaian besar teras yang dibuat ditambahkan dengan pagar. Penambahan ini berfungsi 2, yaitu sebagai keamanan agar orang tidak jatuh kesungai dan sebagai penanda batas teritori bangunan. Namun dikasus teras 1, 2, dan 5 terjadi perubahan teritori teras. Teritori teras bangunan melebar akibat dari kebutuhan ruang yang lebih besar dan anggapan sipemilik bahwa itu wilayah kepemilikannya.

Karakter keempat, penggunaan material kayu yang mendominasi hampir seluruh elemen setting teras. Pagar kayu digunakan sebagai penanda teritori teras dan lantai bangunan. Perabot serta elemen pendukung sebagian besar menggunakan material kayu. Banyaknya penggunaan material kayu pada teras/ bangunan dikarenakan pengaplikasian material kayu yang lebih mudah dan murah pada lokasi bangunan/ rumah. Material kayu yang digunakan juga sewaktu-waktu dapat mudah dibongkar dan dapat digunakan lagi untuk keperluan lain. Sehingga lebih hemat dari segi biaya dan waktu, karena di kampung Bansir mayoritas penduduk kelas menengah- menengah kebawah.

\section{Daftar Pustaka}

Haryadi, B. Setiawan (1996). Arsitektur Lingkungan dan Perilaku, Suatu Pengantar ke Teori, Metodologi dan Aplikasi, Direktorat Jendral Pendidikan. Yogyakarta

Helmi, Avin Fadilla,(1999). Beberapa teori psikologi lingkungan, Universitas Gadja Mada. Yogyakarta

Laurens, Joyce M (2001). Studi Perilaku Lingkungan, Percetakan Universitas Kristen Petra. Surabaya

Laurens, Joyce M (2004). Arsitektur dan Perilaku Manusia, Grasindo. Jakarta Prabowo, Hendro (1998). Arsitektur Psikologi dan Masyarakat, Universitas Gunadarma. Jakarta 